\title{
The Bushmaster (Cuaima) snake (Lachesis muta muta) of the Neotropical forest: the description of several haemostatic and biological activities in its venom
}

\section{La serpiente Bushmaster (Cuaima) (Lachesis muta muta) del bosque Neotropical: descripción de varias actividades hemostáticas y biológicas en su veneno}

\author{
Yuyibeth Montero ${ }^{1}$ (D), María Eugenia Girón ${ }^{1}$ (D), Rafael Medina ${ }^{1}$, Belsy Guerrero² (D), \\ Luis Fernando Navarrete ${ }^{1}$ (D) and Alexis Rodríguez-Acosta ${ }^{1 *}$ (iD)
}

\begin{abstract}
${ }^{1}$ Laboratorio de Inmunoquímica y Ultraestructura, Instituto Anatómico "José Izquierdo" de la Universidad Central de Venezuela. Caracas, Bolivarian Republic of Venezuela. 'Laboratorio de Fisiopatología, Centro de Medicina Experimental, Instituto Venezolano de Investigaciones Científicas (IVIC). Caracas, Bolivarian Republic of Venezuela.

Email: rodriguezacosta1946@yahoo.es
\end{abstract}

\begin{abstract}
Cuaima (Lachesis muta muta)( $\mathrm{Lmm})$ is responsible for particular envenomations that occur mainly in people who are exploring forest areas, in logging activities, mining exploitation (mainly gold and diamonds) or indigenous people who live in small communities and develop their vital activity in tropical and subtropical jungles of the Venezuelan Lmm territory. A fibrinolytic toxin has been purified from the venom of bushmaster cuaima by size exclusion chromatography Sephacryl 300 chromatography column. Fractions collected with high fibrinolytic and scarce haemorrhagic activities were further fractionated by a cationic exchange CarboxymetilSepharose (CMS) chromatography column. From CMS was obtained a molecular mass $\sim 26 \mathrm{kDa}$ single band by SDS-PAGE, called Yuyilysin, which had fibrinolytic activity that was completely lost after treatment with ethylene di-amine tetra acetic acid (EDTA). In conclusion, Yuyilysin showed a broader spectrum of activities, with moderate haemorrhagic activity, non-oedematogenic achievement, but strong fibrinolytic and coagulant actions.
\end{abstract}

Key words: Fibrinolytic activity; neotropical forest; metalloproteases; Turimiquire range; Yuyilysin

\section{RESUMEN}

La serpiente Cuaima (Lachesis muta muta) (Lmm) es responsable de envenenamientos que ocurren principalmente en personas que están explorando áreas forestales, en actividades de tala, explotación minera (principalmente oro y diamantes) o pueblos indígenas que viven en pequeñas comunidades y desarrollan su actividad vital en las selvas tropicales y subtropicales del territorio de $\mathrm{Lmm}$ venezolano. Se ha purificado una toxina fibrinolítica del veneno de la cuaima mediante cromatografía de exclusión molecular, en columna de cromatografía Sephacryl 300. Las fracciones recolectadas con actividad fibrinolítica alta y escasa acción hemorrágica se fraccionaron adicionalmente mediante una columna de cromatografía de intercambio catiónico CarboximetilSepharose (CMS). A partir de CMS se obtuvo una banda única mediante SDS-PAGE, de masa molecular $\sim 26 \mathrm{kDa}$, denominada Yuyilysin, la cual presentaba actividad fibrinolítica que se perdía por completo tras el tratamiento con ácido etilendiamina tetraacético (EDTA). En conclusión, la yuyilisina mostró un espectro de actividades más amplio, con actividad hemorrágica moderada, no edematogénica, pero con acciones fibrinolíticas y coagulantes intensas.

Palabras clave: Actividad fibrinolítica; bosque neotropical; metaloproteasas; cordillera Turimiquire; Yuyilysin 


\section{INTRODUCTION}

Each year, beyond the predictable 140,000 deaths that take place worldwide by snakebite envenomation, $\sim 175$ (1.25\%) deceases happen in Venezuela [18]. In the wilderness natural world there are flora and fauna with the ability to produce toxins that can modify the normal physiological processes of mammals [9]. These toxins, are complex mixtures of proteins, peptides, enzymes, non-enzymes and residues of components such as saccharides and minerals [18]. In some cases, snake venom toxins are used to immobilise the prey and begin to digest it by altering critical points of the victim's haemostatic and neurologic physiological system. This flows from anatomical reservoirs known as venomous glands [21]. Some of these molecules, as metalloproteases bind to fibrinogen and degrade their molecular chains, causing fibrinogen $\alpha, \beta$ and $y$ chains degradation; altering the coagulation process. Others, like the serine proteases have thrombin-like action, decreasing the amount of fibrinogen in the plasma $[17,20]$.

Cuaima (Lachesis muta muta) (Lmm) is the biggest venomous snakes in Venezuela. In range and habitat predilection, the cuaima is usually found in lowlands, near swamps and streams, but infrequently in water. It is responsible for specific envenomations that happen principally in people who are exploring jungle areas, in mapping activities, mining exploitation (mainly gold and diamonds) or indigenous people who live in small communities and develop their vital activity in tropical and subtropical forests of the Venezuelan territory.

The patients that the laboratory staff have had the opportunity to see or those reported by doctors from neighboring rural areas, refer that the conspicuous symptoms of Lmm bite are those involving the haemostatic and nervous system. The Lmm venom also has similar pathophysiological activities as Bothrops venom: coagulant, haemorrhagic and inflammatory, and also presenting enzymes with phospholipase activity with local myotoxicity action. However, it is well differentiated from Bothrops venom because present kininogenase activity, which could explain neurotoxic alterations, observed in the Lmm clinical picture [5].

Since these snakes inhabit tropical forests, it is difficult to capture or maintain them in captivity, which explains the fact that the literature lack of many clinical studies, considering only the effects of their venom in experimental models. Thus, the most relevant symptoms caused by Lmm venom are caused by the action of enzymes from the group of metalloproteases, but little is known about the structure and biological activities of the metalloproteases in $\mathrm{Lmm}$ venom. In the development of the current study, it has come across several anticoagulant/fibrinogenolytic factors of different masses in this venom. The specific toxins unfavorably distressing blood coagulation events may digeste fibrin/fibrinogen or some other coagulation factors in the plasma. These toxins, presenting this attainment on fibrin/fibrinogen have subsequently great importance for their feasible therapeutic potential against intravascular coagulation $[4,13,14]$.

The research objective was to describe among others, the presence of a protein called Yuyilysin, which showed a broader spectrum of activities, with moderate haemorrhagic activity, non-oedematogenic achievement, but strong fibrinolytic and coagulant actions.

\section{MATERIALS AND METHODS}

\section{Reagents}

Lmm dry-pooled venom was obtained from the Serpentarium of the Tropical Medicine Institute of the Universidad Central of Venezuela. Molecular exclusion Sephacryl 300 and cationic exchange Carboxymetil-Sepharose (CMS) chromatography columns were from Sigma Aldrich, USA. Human fibrinogen was from Aniara Corp. (Mason, OH, USA). Other fine chemicals used were purchased from Sigma Chemicals, USA (St. Louis, MO, USA).

\section{Venom collection}

The pooled Lmm snake venom was obtained by manually milking 4 adult specimens of both sexes. The animals were collected at 900 meters above sea level in the Turimiquire range (Anzoátegui State, Venezuela). This mountainous massif includes the north of Monagas, Sucre and Anzoatequi States, Venezuela. The coordinates are between $10.1165^{\circ} \mathrm{N}$ or $10^{\circ} 6^{\prime} 59.5^{\prime \prime} \mathrm{N}$ and $63.8691^{\circ} \mathrm{W}$ or $63^{\circ} 52^{\prime} 8.7^{\prime \prime} \mathrm{W}$. The region of origin of the specimens under study presents a climate influenced by the northeast trade winds ("vientos alisios"), with average annual temperatures of $28^{\circ} \mathrm{C}$ and annual rainfall from 1500 to 2500 millimeters $(\mathrm{mm})$; the vegetation is subtropical rainforest and semi-deciduous forests in the foothills, forming part of the great Andean-American folding [15].

Venom was extracted by allowing the snake to bite into para-film $®$ stretched over a disposable plastic cup. Each venom sample was centrifuged (Allegra $₫$ X-30 Centrifuges, Beckman Coulter, USA) $(500 \times \mathrm{G}$ for 10 minutes ( $\mathrm{min})$, filtered through a 0.45 micrometres $(\mu \mathrm{m})$ filter under positive pressure, and frozen at $-90^{\circ} \mathrm{C}$ (Forma ${ }^{\mathrm{TM}}$ serie 900, Thermo Scientific, USA) until lyophilised.

\section{Protein concentration}

Protein concentration of $\mathrm{Lmm}$ venom was spectrophotometric (Espectrofotometer Hach DR2010, Spain) measured, accepting that 1 unit of absorbance $\mathrm{cm}^{-1}$ of wavelength at 280 nanometres $(\mathrm{nm})$ corresponds to 1 milligram $(\mathrm{mg})$ protein. millilitres $(\mathrm{mL})^{-1}[24]$.

\section{Mice}

Male mice (Mus musculus) from the National Institute of Hygiene $(\mathrm{NIH})$ strain weighing 20 to 22 grams (g) were purchased from the National Institute of Hygiene "Rafael Rangel" (Caracas, Venezuela) animal facility. The mice were kept in cages (Plastic box, Tecniplast, Milano, Italy), at room temperature with 12 hours (h) of natural light and ad libitum water and food until experimentation.

\section{Ethical statement}

Expert personnel arranged all the experimental techniques relating to the use of live animals. Pertinent regulations as well as institutional guidelines, according to protocols ratified by the Institute of Anatomy Ethical Committee of the Universidad Central de Venezuela following the ethical principles in animal research adopted by the World Health Organization (WHO) [26].

\section{Lethality: determination of the lethal dose fifty (LD50) of Lmm venom}

The LD 50 was determined by the Spearman-Kärber method [11], injecting intraperitoneally (ip.) a volume of 0.2 microliter $(\mu \mathrm{L})$ of 
serial dilutions of $\mathrm{Lmm}$ venom (2 to $15 \mathrm{mg} \cdot \mathrm{kilograms}(\mathrm{kg})^{-1}$ body weight), into $\mathrm{NIH}$ mice strain weighing 20 to $22 \mathrm{~g}$. Five groups of 5 mice per dose were used, the animals were kept under observation for a period of $48 \mathrm{~h}$ [23]. Control group animals were injected with isotonic saline.

\section{Fractionation of Lmm venom}

\section{Size exclusion chromatography from Lmm crude venom}

Fifty $\mathrm{mg}$ of Lmm venom were fractionated by Sephacryl 300 $(13 \times 130 \mathrm{~mm})$ chromatography column equilibrated with 0.02 Molar (M) sodium phosphate, $\mathrm{pH} 6.5$ at a flow rate of $0.5 \mathrm{~mL} \cdot \mathrm{min}^{-1}$. The detection of proteins was spectrophotometrically carried out at $280 \mathrm{~nm}$.

\section{Carboxymetil-Sepharose (CMS) cationic exchange chromatography}

Fractions collected on size exclusion chromatography with high fibrinolytic and scarce haemorrhagic activities were further fractionated, by a cationic exchange Carboxymetil-Sepharose (CMS) chromatography column. To carried out this fractionation $2 \mathrm{mg} \cdot \mathrm{mL}^{-1}$ of $\mathrm{Lmm}$ venom fraction FIV (with fibrinolytic activity) was bound to CMS column at $4^{\circ} \mathrm{C}$. The proteins were eluted with phosphate buffer saline (PBS) $0.005 \mathrm{M} \mathrm{NaCL}, \mathrm{pH} 7.5$ through a stepwise gradient using increased ionic strengths $(0.05 \mathrm{M}, 0.1 \mathrm{M}, 0.15 \mathrm{M}$ and $0.2 \mathrm{M})$. Fractions were arranged according to the chromatographic profile and were dialysed against $0.15 \mathrm{M}$ phosphate buffer $-1.5 \mathrm{M}$ ammonium sulphate, $\mathrm{pH}$ 8.0, concentrated by membranes YM10 (Amicon, USA). The eluted material was grouped according to the chromatographic profile at $280 \mathrm{~nm}$. Then, for five high fractions obtained, the fibrinolytic and haemorrhagic activities were tested, dispensed in vials and stored at $-30^{\circ} \mathrm{C}$ (Frigidaire FGVU21F8QF Vertical Freezer, USA) until use. Fraction 5 showed the highest fibrinolytic activity and was chosen for characterisation. A total of 10 runs were carried out to obtain enough protein to test.

\section{Polyacrylamide gel electrophoresis}

The crude Lmm venom and the CMS-5 fraction were run in electrophoresis under reduced conditions (8 - $20 \%)$, using methods $[10,12,22]$ to detect the proteins. For the crude $\mathrm{Lmm}$ venom, the polypeptides found were classified into groups, based on their relative molecular masses, establishing that the very high ones were greater than 200 kilodaltons $(\mathrm{kDa})$, high between $200-66.2 \mathrm{kDa}$, intermediate 66.2 - $21.5 \mathrm{kDa}$ and low between 21.5 - $6.5 \mathrm{kDa}$ and very low those below $6 \mathrm{kDa}[6]$.

\section{Haemorrhagic analysis: minimum haemorrhagic dose (MHD)}

The haemorrhagic activity of the Lmm venom and its CMS-5 fraction was done with a modified Kondo et al. method [8] and expressed as the minimum haemorrhagic dose (MHD), which is the MHD of venom capable of producing a subcutaneous (s.c) haemorrhagic lesion in $2 \mathrm{~h}$ with a diameter of $10 \mathrm{~mm}$. Serial sublethal doses $\left(25,50\right.$ and 100 micrograms $\left.(\mu \mathrm{g}) \cdot \mu \mathrm{L}^{-1}\right)$ of both $\mathrm{Lmm}$ venom or CMS-5 fraction dissolved in isotonic saline solution in a final volume of $0.1 \mathrm{~mL}$ were injected intradermally (i.d) in the abdominal region of 4 male NIH mice. The mice in the control group were injected with isotonic saline. After $2 \mathrm{~h}$, the animals from both trials were sacrificed by cervical dislocation, the skin was dissected and the haemorrhagic area was measured at the inside skin.

\section{Coagulant activity}

Coagulant activity of Lmm venom and its CMS-5 fraction was performed following the method of Salazar et al. [19]. One hundred microlitres $(100 \mu \mathrm{L})$ of citrated plasma or $0.3 \%$ fibrinogen solution in Tris- $\mathrm{HCl}$ buffer, $\mathrm{pH} 7.4$, was incubated in a tube for $3 \mathrm{~min}$ at $37^{\circ} \mathrm{C}$. Then, $100 \mu \mathrm{L}$ of the same buffer and $100 \mu \mathrm{L}$ of thrombin $\left(0.5-15\right.$ International Units (IU) $\left.\cdot \mathrm{mL}^{-1}\right)$ or $100 \mu \mathrm{L}$ of $\mathrm{Lmm}$ venom and CMS-5 fraction samples $\left(0.1-1 \mathrm{mg} \cdot \mathrm{mL}^{-1}\right)$ were supplemented. The solution was by hand mixed carefully in a $37^{\circ} \mathrm{C}$ water bath and the clotting time was verified.

\section{Fibrinolytic analysis}

To assay the fibrinolytic activity of Lmm venom and its CMS-5 fraction was used the modified Bajwa et al. method [4]. Three hundred $\mu \mathrm{L}$ of fibrinogen and $12 \mu \mathrm{L}$ thrombin solution was put into each well of a 24 wells plate. Then, it was delicately agitated. The plate was kept at room temperature until constituent solidified. Afterward, $10 \mu \mathrm{L}\left(1 \mu \mathrm{g} \cdot \mu \mathrm{L}^{-1}\right)$ of $\mathrm{Lmm}$ venom and its CMS-5 fraction was prepared in sterile $0.85 \%$ saline as carrier and positioned in the centre of the fibrin layer, at that time incubated for $24 \mathrm{~h}$ at $37^{\circ} \mathrm{C}$. After the incubation time had passed, the diameter of the lysis area on the fibrin surface was established. Then, $700 \mu \mathrm{L}$ of trichloroacetic acid $10 \%$ were placed at each well to stop the reaction, decanting after 10 min. Fibrinolytic activity was stated as the diameter of the lysis area per microgram of venom $\left(\mathrm{mm}^{2} \cdot \mu^{-1}\right)$. Bothrops colombiensis venom was employed as a positive control and sterile $0.85 \%$ saline as a negative control. The test was also carried out with CMS-5 fraction treated or untreated with ethylene di-amine tetra acetic acid (EDTA).

\section{Oedema-forming activity}

Oedema-forming activity was quantified by a modification of Tan and Saifuddin method [25]. Concisely, groups of 4 mice were injected in the right hind pad with $0.5 \mu \mathrm{g}$ of $\mathrm{Lmm}$ venom and CMS-5 fraction dissolved in $30 \mu \mathrm{L}$ of sterile saline solution. Sterile saline solution was injected into the left footpad as a negative control. At different periods, animals were sacrificed by cervical dislocation and the hind limbs were removed and weighed. The Minimum Oedematising Dose (MED) was defined as the amount of venom that induces a $30 \%$ increase in oedema, with respect to the control hind limb.

\section{RESULTS AND DISCUSSION}

Concerning geographical distribution of Lmm snake, in FIG. 1 was shown the distribution (Turimiquire range) area of the $\mathrm{Lmm}$ snake specimens used in this work

The ophitoxemia caused by Lmm shows local and systemic signs comparable to those seen in bothropic envenomation, such as serious pain at the bite site that extend out to the limbs, with severe and abrupt progressive oedema. In the region nearby the bite: ecchymosis, bullae and necrosis were observed. The systemic area shows gastrointestinal expressions, which produces profuse salivation, abdominal cramping and bloody diarrhoea. Patients also present intense arterial hypotension, bradycardia with fainting or weakness [18].

In the former years, the snake venom research has concentrated on metalloproteases (SVMPs) by its possible medical use in the handling of haemostatic diseases [12]. Metalloproteases with 


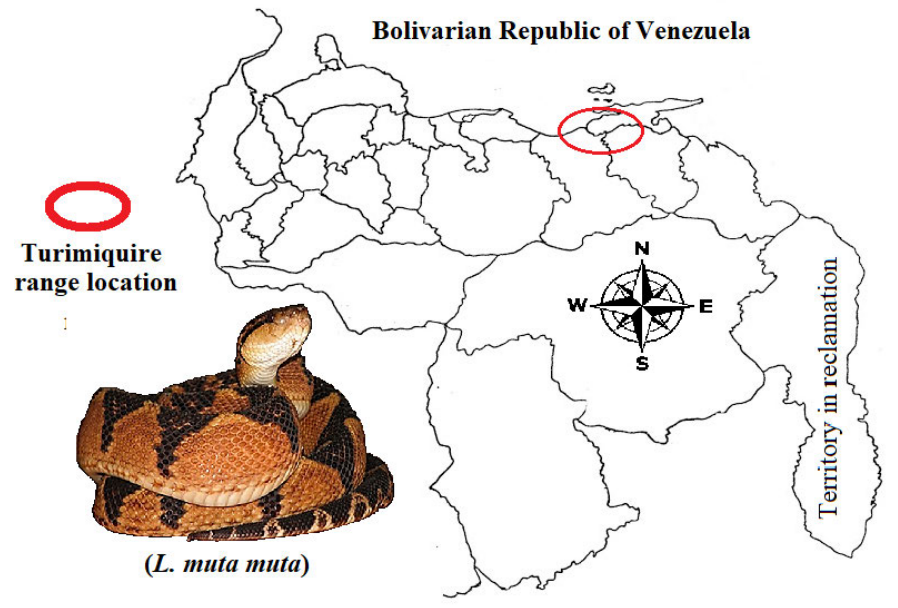

FIGURE 1. Geographical distribution of LMM snake at Turimiquire range (Anzoategui, Monagas and Sucre States, Venezuela)

fibrin(ogen)olytic action are effective for thrombosis usage since they drop plasma fibrinogen and break up fibrin coagules [19].

Limited performs describing haemostatic activities with $\mathrm{Lmm}$ venom has been carried out. Until now only few proteins have been purified from this snake venom, among them, a C-type lectin-like fraction (MC-1) with coagulant activity, like protein from Lachesis muta stenophyrs venom and also a glycoprotein enzyme with thrombinlike activity of $\sim 37 \mathrm{kDa}$ molecular mass were also described [2, 3]. Sanchez et al. [21] isolated a proteinase of $\sim 33 \mathrm{kDa}$ with plasminogenactivating action from Lmm (bushmaster) snake venom. In this work, the total venom Lmm protein concentration displayed a concentration of $14.26 \mathrm{mg} \cdot \mathrm{mL}^{-1}$. The CMS-5 fraction presented a concentration of $0.49 \mathrm{mg} \cdot \mathrm{mL}^{-1}$.

The venom fractionation was carried out by two chromatographic procedures, first a Sephacryl S-300 molecular exclusion chromatography, which the eluates processed in native conditions, displayed a profile characterised by 8 peaks or fractions obtained when reading at $\lambda 280 \mathrm{~nm}$, which were identified with numbers from I to VIII (FIG. 2).

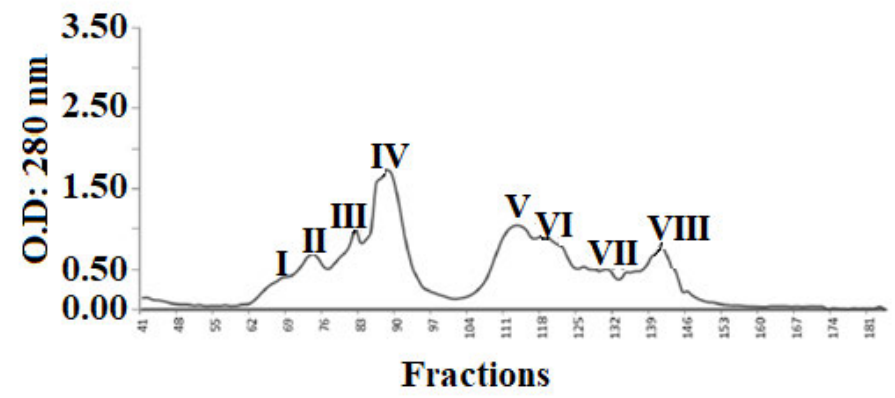

FIGURE 2. Molecular Exclusion Chromatography. Sequential purification steps of $\mathrm{Lmm}$ venom $(50 \mathrm{mg}$ ) on Sephacryl-300 (S-300) that was equilibrated with $50 \mathrm{mM}$ ammonium acetate buffer, pH 6.9. Fraction IV revealed high fibrinolytic activity
Procoagulant, fibrinolytic and haemorrhagic activities were tested in the fractions of this venom. From the 8 fractions gathered by size exclusion chromatography, strong fibrinolytic activity was identified in fraction FIV, which represented $48.7 \%$ of the venom components.

Subsequently, a chromatography of cationic exchange, where the eluting peaks (1 to 5) tops were assayed for fibrinolytic activity. The peak F5 (CMS-5) showed high fibrinolytic activity (FIG. 3).

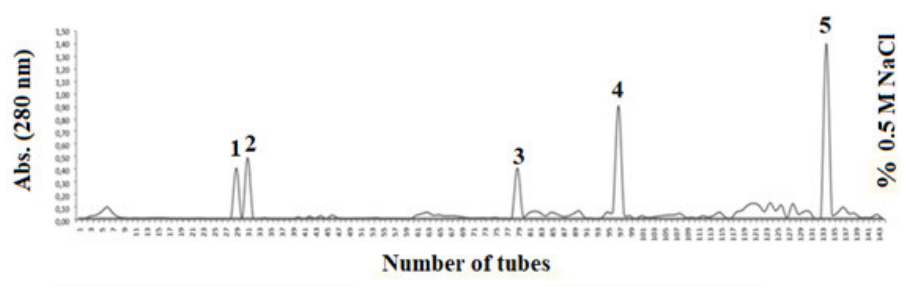

FIGURE 3. Fractionation of LMM fraction IV venom by Cationic Exchange Column. Fraction IV (2 mg) was chromatographied on a Carboxi-methyl-Sepharose column cationic exchange column equilibrated with $50 \mathrm{mM}$ tris- $\mathrm{HCl}$ buffer, $\mathrm{pH} 7.0$, at a flow rate of $1.0 \mathrm{mg} \cdot \mathrm{min}^{-1}$ at $4^{\circ} \mathrm{C}$. After elution of unbound material, a linear $\mathrm{NaCl}$ gradient from 0 to $1 \mathrm{M}$ (pH 9.0) was carried out. Fraction 5 (CMS-5) showed intense fibrinolytic activity

The Lmm crude venom molecular masses determined by sodium dodecyl sulphate-polyacrylamide gel electrophoresis (SDS-PAGE) presented a band distribution, which included proteins of high, medium and low molecular masses. In FIG. 4, the SDS-PAGE profile of the total venom is shown with approximately 12 protein bands, with molecular masses between approximately 12 and $225 \mathrm{kDa}$. The profile of the FIV fraction obtained from molecular exclusion chromatography showed 8 major protein bands, with molecular masses between approximately 20 and 105 kDa. In the other hand, CMS-5 fraction (now called Yuyilysin) was a very clean single $\sim 26 \mathrm{kDa}$ band by SDS-PAGE (8 - $20 \%$ ), which was obtained from cation exchange chromatography, under reduced conditions (FIG. 5).

According to its lethality, the Lmm venom used in this work was less toxic than bothropic (LD50: $\sim 0.86 \mathrm{mg} \cdot \mathrm{kg}^{-1}$ body weight) [20] and crotalic (LD50: $\sim 0.144 \mathrm{mg} \cdot \mathrm{kg}^{-1}$ body weight) [1] venoms. $\mathrm{Lmm}$ venom in the current work presented a LD50 of $\sim 9.01 \mathrm{mg} \cdot \mathrm{kg}^{-1}$ body weight; however accidents caused by this snake are always highly serious, due to the amount of venom they manage to inject (roughly $\sim 20 \mathrm{mg}$ total) [18].

With reference to a haemorrhagic analysis, testing the minimum haemorrhagic dose (MHD), this venom presented $15.88 \mu \mathrm{g} \pm 6.25$ $\mu \mathrm{g} \cdot$ mouse $^{-1}(\mathrm{n}=5)$. While animals treated with $\mathrm{NaCl}$ at $0.85 \%$, the development of haemorrhagic lesion was not observed. Yuyilysin showed $10.1 \pm 1.4 \mu \mathrm{g} \cdot$ mouse $^{-1}(n=5)$ (TABLE 1). Most of the metallo- and serine-proteinases present in snake venoms produce local haemorrhages by direct or indirect actions on blood vessel endothelium [12]. But, on the other hand, these proteases represent substantial tools for coagulation and thrombosis 


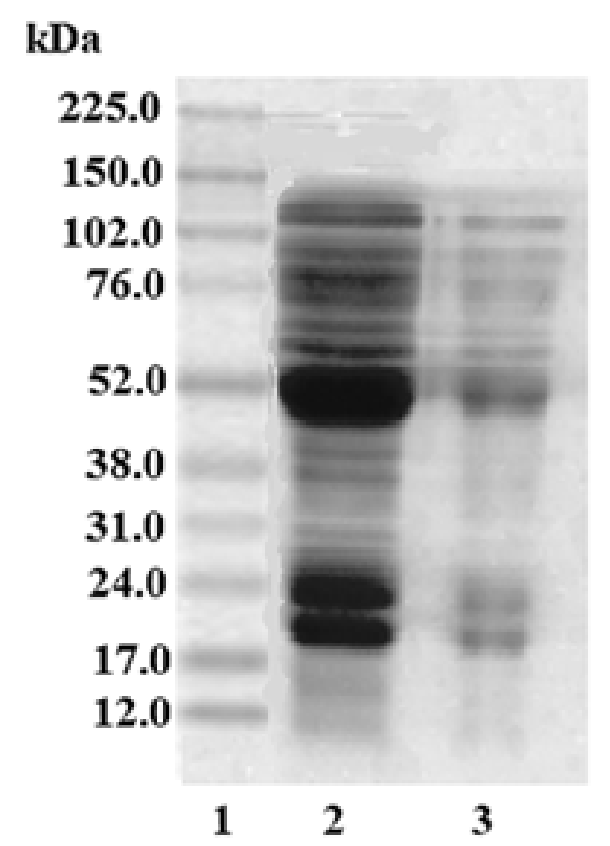

FIGURE 4. SDS-page (8 - $20 \%$ ) of crude LMM venom. (1) Molecular mass markers (10 $\mu \mathrm{l})$ (Bio-Rad, California, U.S.A). (2) Lmm crude venom. (3) Fraction IV. Stained with Coomasie blue
TABLE I

Biological and haemostatic activities of $\mathrm{Lmm}$ venom

\begin{tabular}{|c|c|c|}
\hline \multirow[b]{2}{*}{ Activity } & \multicolumn{2}{|c|}{ Component } \\
\hline & $\begin{array}{l}\text { Lmm } \\
\text { venom }\end{array}$ & $\begin{array}{l}\text { Yuyilysin } \\
\text { fraction }\end{array}$ \\
\hline $\begin{array}{c}\text { LD50 } \\
\left(\mu \mathrm{g} \cdot \mathrm{mouse}^{-1}\right)\end{array}$ & 18.02 & N.D \\
\hline $\begin{array}{c}\text { Activity Coagulant - Plasma } \\
\left.\text { (IU Th· } \mu g^{-1}\right)\end{array}$ & 23.0 & 75.0 \\
\hline $\begin{array}{l}\text { Activity Coagulant - Fibrinogen } \\
\text { (IU Th } \mu \mu^{-1} \text { ) }\end{array}$ & 17.0 & 88.0 \\
\hline $\begin{array}{c}\text { MHD } \\
\left(\mu \mathrm{g} \cdot \mathrm{mouse}^{-1}\right)\end{array}$ & $15.9 \pm 6.3$ & $10.1 \pm 1.4$ \\
\hline $\begin{array}{c}\text { MED } \\
\left(\mu \mathrm{g} \cdot \mathrm{mouse}^{-1}\right)\end{array}$ & $0.12 \pm 0.03$ & 0 \\
\hline $\begin{array}{l}\text { Activity Fibrinolytic } \\
(\mathrm{mm})\end{array}$ & $42.0 \pm 0.1$ & $26.5 \pm 1.2$ \\
\hline
\end{tabular}

LD50: Lethal dose fifty; IU Th: International units of thrombin; MHD; minimum haemorrhagic dose; MED: Minimun oedematising dose

treatments and research of the mechanism implicated in circulatory system injury. This effective dose must be related with low molecular mass metalloproteases such as $\alpha$ and $\beta$ ( 22 kDa LHTa and $\sim 23 \mathrm{kDa} \mathrm{LHTb}$ ), proteases with potent haemorrhagic activity found in the crude venom of $\operatorname{Lmm}[16,27]$. In the assessment of the haemorrhagic lesions were very well perceived on the skin of treated mice. These damages augmented its strength in a dosedependent manner. Haemorrhage is a common expression in human and animal victims following a bite by Lmm snake [18].

Concerning coagulant activity, the Lmm crude venom studied showed in vitro pro-coagulant effect, agreeing to the conditions of this work, with a dose-dependent association characterised by a reduction in the time required for induction of plasma coagulation by rising the dose of the venom tested. An activity on plasma of 23.0 IU Thrombin (Th. $\mathrm{mg}^{-1}$ of Lmm crude venom was obtained. When using purified human fibrinogen as substrate, the $\mathrm{Lmm}$ crude venom presented an activity of $17.0 \mathrm{IU} \mathrm{Th} \cdot \mathrm{mg}^{-1}$ (TABLE 1). Yuyilysin presented a pro-coagulant effect in vitro, with a dosedependent relationship characterized by a reduction in the time necessary for induction of plasma coagulation. An activity on plasma of $75.0 \mathrm{IU}$ Th. $\mathrm{mg}^{-1}$ was achieved. When using purified human fibrinogen as substrate, the Yuyilysin revealed to be effective with an activity of $80.0 \mathrm{IU} \mathrm{Th} \cdot \mathrm{mg}^{-1}$ (TABLE 1). As an interesting finding, the coagulant activity of Yuyilysin was higher in plasma and fibrinogen than crude venom, probably due to its higher activity when pure.

When the oedema-forming activity was assayed, the Lmm venom induced mild oedema after $30 \mathrm{~min}(23.3 \pm 2.8 \%)$. In contrast, Yuyilysin did not show perceptible oedema after 30 min (TABLE 1). The oedema activity induced by $\mathrm{Lmm}$ venom, presented a dependent relationship dose showing an increase in the percentage of oedema that was directly proportional to the venom dose evaluated. In some of treated animals was observed that the oedema extended further than the foot pad, involving the entire limb tested, an effect that was exhibited with a low dose, when compare with its respective control.
FIGURE 5. SDS-Page (12\%) of CMS-5 fraction obtained from the Cationic Exchange Carboxymethyl-Sepharose Chromatography Column. (1) Molecular mass markers. (2) CMS-5 26 kDa (now Yuyilysin) fraction 
Apropos the fibrinolytic activity, was demonstrated that testing on plates using fibrin in the absence of pasminogen and expressed as specific activity $\left(\mathrm{mm}^{2} \cdot \mu^{-1}\right)$, it was found that the venom of $\mathrm{Lmm}$ had a high fibrinolytic activity $\left(42 \pm 0.1 \mathrm{~mm}^{2} \cdot \mu \mathrm{g}^{-1}\right)$. It was observed, within the lysis area a well-defined halo (data not shown). Yuyilysin displayed high fibrinolytic activity $\left(26.5 \pm 1.2 \mathrm{~mm}^{2} \cdot \mu \mathrm{g}^{-1}\right)$. Negative control (isotonic saline) exhibited no activity, while the positive control (B. colombiensis venom) entirely lysed the plate (FIG.6).

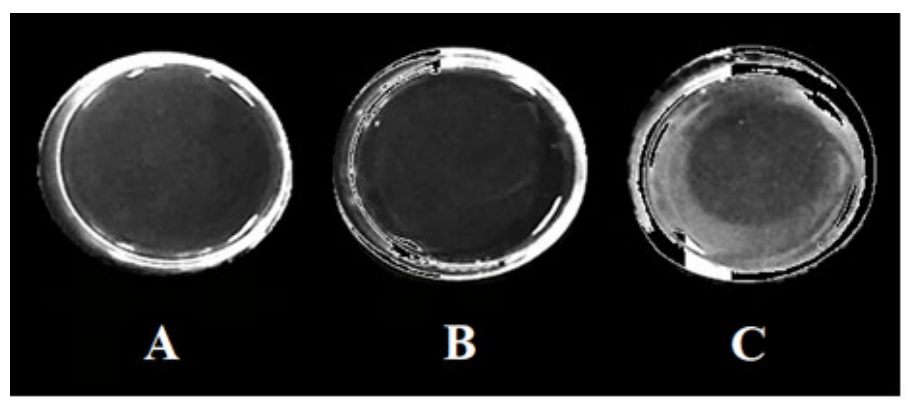

FIGURE 6. Fibrinolytic activity of Yuyilysin. It was determined on plaques using fibrin in the absence of pasminogen and expressed as specific activity $\left(\mathrm{mm}^{2} \cdot \mu^{-1}\right)$. Yuyilysin showed high fibrinolytic activity $\left(26.5 \pm 1.2 \mathrm{~mm}^{2} \cdot \mu^{-1}\right)$. A) Negative control (isotonic saline). (B) Positive control (Bothrops colombiensis venom) (entirely lysed). C) Yuyilysin

The Yuyilysin fibrinolytic activity was completely lost after treatment with ethylene di-amine tetra acetic acid (EDTA), which confirms its metalloprotease nature. The pattern of degradation of inter-crossed fibrin, had a very comparable behaviour. Fibrinolytic in fibrin plate activity was analogous in the presence and absence of plasminogen, which advises that these enzymes do not activate plasminogen. Yuyilysin fibrinolytic with low haemorrhagic activity must be explored as thrombolytic agent by thrombus dissolution or by preventing its formation. Enzymes with fibrinolytic competences break up fibrin mesh into fibrin degradation fragments. Limited studies in mice with inactivation of the central components of the fibrinolytic system have proven the physiological relevance of the system in these directions, advising participation of other proteolytic systems, mainly the matrix metalloprotease (MMP) system [11]. Several metalloprotease anticoagulants also show haemorrhagic or haemolytic activities [7].

The most of the fibrinolytic alternatives currently existing for therapeutically treatments acts via plasminogen activation, But, every one of these agents even now go through secondary side effects and significant deficiencies, including necessity of large therapeutic dose, little plasma half-life, restricted fibrin specificity, reocclusion and bleeding difficulties [17]. Therefore, it is essential to discovery other fibrinolytic enzymes [12] from the diverse natural world, comprising venomous snakes and/or plant fonts.

\section{CONCLUSIONS}

At present, it has been exposed that the Lmm venom has in vitro procoagulant activity similar to bothropic venoms, The Lmm crude venom displayed haemorrhagic and anticoagulant activities, and
Yuyilysin, an enzyme categorized as a P-I metalloprotease, was recognised in this venom. This study describes the characterisation of one fibrinolytic Type I metalloprotease yuyilysin from the Lmm venom, which represent one of the first original fibrinolytic enzymes described in this venom.

\section{ACKOWLEGMENTS}

Thank to the Immunochemistry and Ultrastructural Laboratory (UCV) workers. Funding for this project was provided by grant from the Science and Technology Fund (FONACIT) programs (PEI 201400352) (Universidad Central de Venezuela).

\section{CONFLICT OF INTEREST}

The authors have declared no conflict of interest.

\section{BIBLIOGRAPHIC REFERENCES}

[1] AGUILAR, I.; GUERRERO, B.; SALAZAR, A.M.; GIRÓN, M.E.; PÉREZ, J.; SÁNCHEZ, E.; RODRÍGUEZ-ACOSTA, A. Individual venom variability in the South American rattlesnake Crotalus durissus cumanensis. Toxicon. 50: 214-224. 2007.

[2] ARAGON-ORTIZ, F.; GUBENSEK, F. A thrombin-like enzyme from bushmaster (Lachesis muta stenophyrs) venom. Toxicon. 31: 1435-1443. 1993.

[3] ARAGON-ORTIZ, R.; MENTELE, A.; AUERSWALD, EA. Amino acid sequence of a lectin-like protein from Lachesis muta stenophyrs venom. Toxicon. 34: 763-769. 1996.

[4] BAJWA, S.S.; MARKLAND, F.S.; RUSSELL, F.E. Fibrinolytic enzyme(s) in western diamondback rattlesnake (Crotalus atrox) venom. Toxicon. 18: 285-90. 1980.

[5] DAMICO, D.C.S.; BUENO, L.G.F.; RODRIGUES-SIMIONI, L.; MARANGONI, S.; CRUZ-HOFLING, M.A.; NOVELLO, J.C. Neurotoxic and myotoxic actions from Lachesis muta muta (surucucu) whole venom on the mouse and chick nervemuscle preparations. Toxicon. 46: 222-229. 2005.

[6] GIRÓN, M.E.; ESTRELLA, A.; SÁNCHEZ, E.E.; GALÁN, J.; TAO, W.A.; GUERRERO, B.; SALAZAR, A.M.; RODRÍGUEZACOSTA, A. Purification and characterization of a metalloproteinase, Porthidin-1, from the venom of Lansberg's hog-nosed pitvipers (Porthidium lansbergii hutmanni). Toxicon. 57: 608-618. 2011.

[7] KINI, R.M. Anticoagulant proteins from snake venoms: structure function and mechanism. Biochem. J. 397: 377-387. 2006.

[8] KONDO, H.; KONDO, S.; IKESAWA, H.; MURATA, R.; OSHAKA, A. Studies on the quantitative method for determination of hemorrhagic activity of Habu snake venom. Jpn. J. Med. Sci. Biol. 13: 43-51. 1960.

[9] KOVCHA, E. The origin of snakes and evolution of the venom apparatus. Toxicon. 25: 65-106. 1987.

[10] LAEMMLI, U. Cleavage of structural proteins during the assembly of the head of bacteriophage T-4. Nature. 227: 608-609. 1970.

[11] LIJNEN, H.R. Matrix metalloproteinases and cellular fibrinolytic activity. Biochemistry (Moscow). 67(1): 92-98. 2002. 
[12] MARKLAND, F.S. Snake venom and hemostatic system. Toxicon. 36: 1749-1800. 1998.

[13] MARSH, N.; WILLIAMS, V. Practical applications of snake venom toxins in haemostasis. Toxicon. 45: 1171-1181. 2005.

[14] MARSH, N.A. Diagnostic uses of snake venom. Haemostasis. 31: 211-217. 2000.

[15] PIFANO, F. Investigación y docencia en Medicina Tropical. Arch. Ven. Med. Trop. Parasitol. Med. 4: 1-203. 1961.

[16] RAN, Y.L.; ZHENG, S.D.; TU, AT. Biochemical characterization of two hemorrhagic proteases from the venom of Lachesis muta (bushmaster). Chem. Res. Toxicol. 1: 337-342. 1988.

[17] REDDY, D.S. Newer thrombolytic drugs for acute myocardial infarction. Indian. J. Exp. Biol. 36: 1-15. 1998.

[18] RENGIFO, C.; RODRÍGUEZ-ACOSTA, A. Serpientes, Veneno y Tratamiento Médico en Venezuela. Caracas: Universidad Central de Venezuela. Pp. 1-272. 2019.

[19] SALAZAR, A.M.; RODRIGUEZ-ACOSTA, A.; GIRÓN, M.E.; AGUILAR, I.; GUERRERO, B. A comparative analysis of the clotting and fibrinolytic activities of the snake venom (Bothrops atrox) from different geographical areas in Venezuela. Thromb. Res. 120: 95-104. 2007.

[20] SÁNCHEZ, E.E.; GIRÓN, M.E.; UZCÁTEGUI, N.L.; GUERRERO, B.; SAUCEDO, M.; CUEVAS, E.; RODRÍGUEZ-ACOSTA, A. Biochemical and biological characterisation of lancehead (Bothrops venezuelensis Sandner 1952) snake venom from the Venezuelan Central Coastal range. Bol. Malariol. Sal. Amb. 54: 138-149. 2014.
[21] SANCHEZ, E.F.; SANTOS, C.I.; MAGALHAES, A.; DINIZ, C.R.; FIGUEIREDO, S.; GILROY, J.; RICHARDSON, M. Isolation of a proteinase with plasminogen-activating activity from Lachesis muta muta (bushmaster) snake venom. Arch. Biochem. Biophys. 378: 131-41. 2000.

[22] SCHÄGGER, H.; VON JAGOW, G. Tricine-sodium dodecyl sulfate-polyacrylamide gel electrophoresis for the separation of proteins in the range from 1 to $100 \mathrm{kDa}$. Anal. Biochem. 166: 368-379. 1987.

[23] SPEARMAN-KÄRBER, R, Alternative methods of analysis for quantal responses. In: Finney, D (Ed.). Statistical Method in Biological Assay. 2nd.Ed. Charles Griffin, London. 178 pp. 1964.

[24] STOSCHECK, C.M. Quantitation of protein. Methods Enzymol. 182: 50-68. 1990.

[25] TAN, N.H.; SAIFUDDIN, M.N. Comparative study of the oedema-inducing activity of snake venoms. Comp. Biochem. Physiol C. Comp. Pharmacol. Toxicol. 97: 293-296. 1990.

[26] WORLD HEALTH ORGANIZATION. Guidelines for the Management of Snakebites. 2nd Ed. WHO. Pp. 1-141. 2016.

[27] ZANOTTY, Y.; ÁLVAREZ, M.; PERDOMO, L.; SANCHEZ, E.E.; GIRON, M.E.; SUNTRAVAT, M.; MONTERO, Y.; MEDINA, R.; NAVARRETE, L.F.; RODRÍGUEZ-ACOSTA, A. Mutacytin-1, a new C-Type lectin-like protein from the Venezuelan Cuaima (Lachesis muta muta Linnaeus, 1766) (Serpentes: Viperidae) snake venom inducing cardiotoxicity in developing zebrafish (Danio rerio) embryos. Zebrafish. 16: 379-387. 2019. 